\title{
Metode Offline Forensik Untuk Analisis Digital Artefak Pada TOR Browser Di Sistem Operasi Linux
}

\author{
Wisnu Sanjaya ${ }^{\text {a,1,** }}$, Bambang Sugiantoro ${ }^{\text {b,2, }}$, Yudi Prayudi ${ }^{\text {a,3 }}$ \\ ${ }^{a}$ Magister Teknik Informatika, Universitas Islam Indonesia, Jl Kaliurang KM 14.5, Sleman, Yogyakarta, 55584, Indonesia \\ ${ }^{\mathrm{b}}$ Magister Teknik Informatika, UIN Sunan Kalijaga Yogyakarta, Jl Marsda Adisucipto, Yogyakarta, 55281, Indonesia \\ ${ }^{1}$ wisnuksl@gmail.com; ${ }^{2}$ bambang.sugiantoro@uin-suka.ac.id; ${ }^{3}$ prayudi@uii.ac.id \\ * Koresponsendi penulis
}

\section{ARTICLE INFO}

Article history

Menerima 11 Mei 2020

Revisi 1 Juni 2020

Diterima 3 Juni 2020

Kata Kunci

Browser Forensic

TOR

Linux

Offline Forensic

\section{ABSTRACT}

The rapid development of the IT world has covered all aspects of life and among IT technology products are the creation of Operating Systems and Web browser applications. Linux and TOR Browser are a combination that is widely used in the field of security, but unfortunately many are abused by that person in a crime. The motivation for using both is to eliminate or minimize digital traces of exploration activities so that it will be difficult to find digital evidence in a crime. This study proposes a phased framework for the analysis of the TOR Browser in the Linux Operating System which aims to provide solutions in forensic investigations using offline forensic methods. The use of offline forensic methods to obtain detailed information from digital evidence on a computer in an inactive state is done because most of the evidence using the live forensic method does not succeed in finding digital evidence that is omitted by the perpetrators.

This is an open access article under the CC-BY-SA 4.0 license.

\section{Pendahuluan}

Ditemukannya internet berdampak terhadap kehidupan manusia yg cukup drastis, dimana internet digunakan untuk menghubungkan antar individu yg berbeda secara geografi dalam hampir seluruh aktivitas keseharian. Selain Manfaat baik, internet juga banyak disalahgunakan untuk melakukan tindakan kejahatan yang bersifat negative. Oleh Sebab itu penulis mencoba melakukan penelitian untuk mengungkap aktifitas penggunaan web di internet yang dilakukan dengan menggunakan metode offline forensic, karena kebanyakan penelitian menggunakan metode live forensic. 


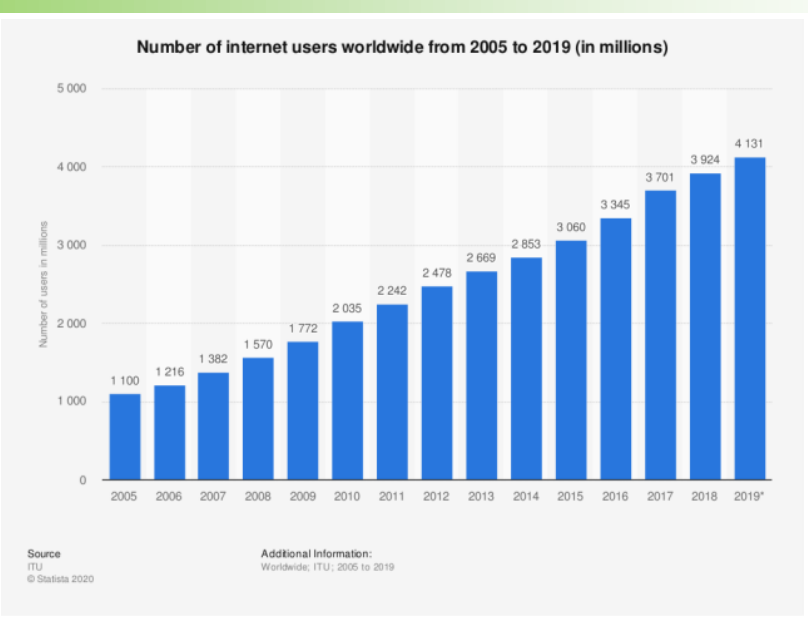

Gambar 1.0 Statistik Pengguna Internet

(Sumber: https://www.statista.com/statistics/273018/number-of-internet-users-worldwide/)

Web browser merupakan sebuah aplikasi software penting yang biasa digunakan untuk mengakses internet baik untuk mencari informasi, bersosial media dan bertransaksi internet [1].

Web browser memiliki kemampuan untuk menyimpan aktivitas browsing dari sesi pengguna yang berupa informasi url yg dikunjungi, berkas dan gambar yang disimpan, pencariaan, cokies dan informasi lainya. Informasi tersebut tersimpan dalam komputer dan bisa diakses atau diambil oleh pengguna lainya[2].

Semakin pedulinya pengguna terhadap privasi aktivitas browsing, maka mereka menghendaki web browser mampu untuk tidak meninggalkan jejak informasi terkait aktifitas browsing dari sesi pengguna [3]

TOR Browser adalah Web browser yang secara default sdh mempunyai kemampuan menjaga privasi, sehingga keberadaan dan identitas pengguna tidak terekpos ke internet. Perute onion dikembangkan lebih jauh oleh DARPA pada tahun 1997. Versi alpha dari TOR, yang dikembangkan oleh ilmuwan Syverson dan komputer Roger Dingledine dan Nick Mathewson dan kemudian disebut proyek Onion Routing, atau proyek TOR, diluncurkan pada tanggal 20 September 2002[4]

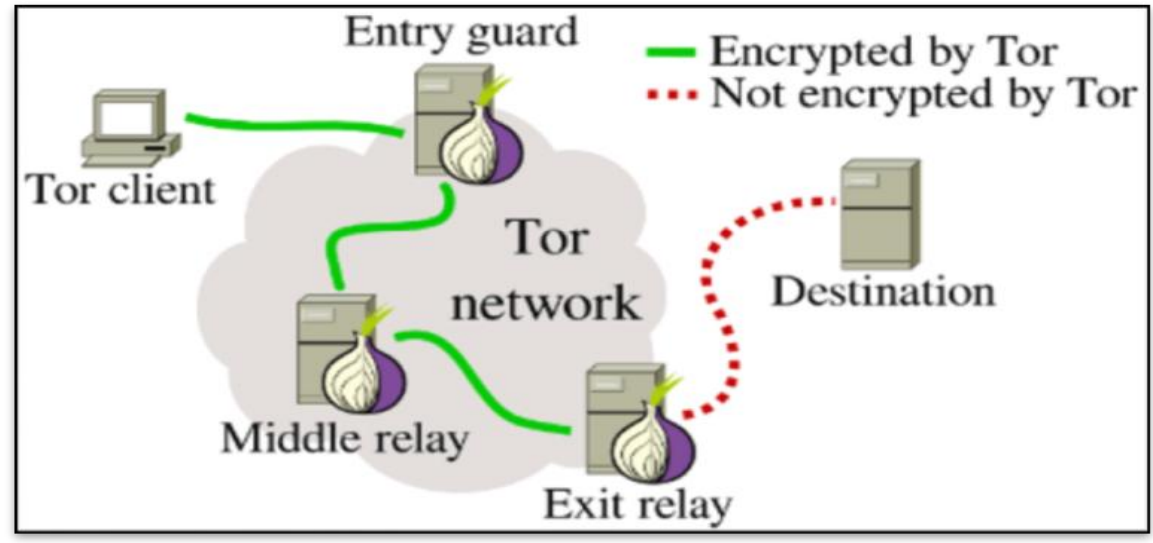

Gambar 1.1 Jaringan TOR

(Sumber: https://mybroadband.co.za/news/internet/165690-tor-network-what-it-is-and-how-it-works.html)

Kali Linux adalah salah satu distro linux yg dikenal cukup populer untuk kegunaan uji keamanan jaringan dan digital forensic. Kali linux memiliki banyak tools untuk keperluan uji keamanan dan mampu berjalan di beberapa arsitektur komputer[5]. 


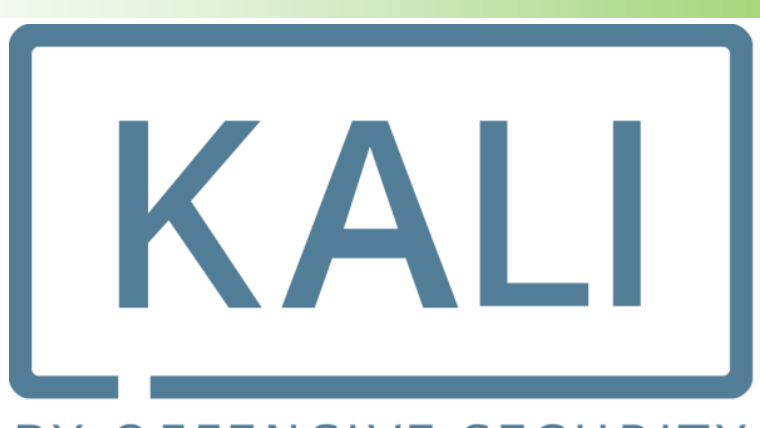

BY OFFEN SIVE SECURITY

Gambar 1.2 Logo kali linux

(Sumber: https://en.wikipedia.org/wiki/File:Kali_Linux_2.0_wordmark.svg)

\section{Tinjauan Pustaka}

\subsection{Penelitian Terdahulu}

Penelitian sejenis tentang Private browser telah banyak dilakukan, pada era yang serba terbuka saat ini pengguna internet yang menginginkan privasinya terlindungi. Dari sisi aplikasi TOR Browser adalah salah satu aplikasi perambah web yang mempunyai kemampuan untuk melindungi privasi penggunanya dan cukup banyak penggunanya.

Tabel 2.1 Literatur Review

\begin{tabular}{|c|c|c|c|c|}
\hline Paper Utama & $\begin{array}{c}\text { Offline } \\
\text { Forensic }\end{array}$ & $\begin{array}{l}\text { Private } \\
\text { Browser }\end{array}$ & $\begin{array}{c}\text { Kali } \\
\text { Linux }\end{array}$ & Pengujian \\
\hline (Hassan \& Jaber, 2017) & $\sqrt{ }$ & & & $\begin{array}{l}\text { Komparasi ektrasi data metode } \\
\text { Online dengan Offline pada } \\
\text { layanan cloud }\end{array}$ \\
\hline (Kolhe \& Ahirao, 2017) & $\sqrt{ }$ & & & $\begin{array}{l}\text { Analisis malware dengan akuisisi } \\
\text { image menggunakan perbandingan } \\
\text { dua buah metode }\end{array}$ \\
\hline $\begin{array}{l}\text { (Shree Krishna } \\
\text { Lamichhane, 2016) }\end{array}$ & & & $\sqrt{ }$ & $\begin{array}{l}\text { Penggunaan Kali Linux tools untuk } \\
\text { uji keamanan Jaringan }\end{array}$ \\
\hline $\begin{array}{l}\text { (Babincev \& Vuletic, } \\
\text { 2016) }\end{array}$ & & & $\sqrt{ }$ & $\begin{array}{l}\text { Pengujian Keamanan aplikasi web } \\
\text { menggunakan Kali Linux }\end{array}$ \\
\hline (Keller, 2016) & & $\sqrt{ }$ & & $\begin{array}{l}\text { Pencarian jejak digital dari tor } \\
\text { browser }\end{array}$ \\
\hline (Adautin \& R, 2015) & $\sqrt{ }$ & & & $\begin{array}{l}\text { Metode offline diterpakan pada } \\
\text { google portable browser private } \\
\text { session }\end{array}$ \\
\hline $\begin{array}{l}\text { (Al-Khaleel, Bani- } \\
\text { Salameh, \& Al-Saleh, } \\
\text { 2014) }\end{array}$ & & $\sqrt{ }$ & & $\begin{array}{l}\text { Pencarian tor browser artefacs } \\
\text { secara online forensic pada } \\
\text { memory }\end{array}$ \\
\hline (Mulazzani, 2014) & & $\sqrt{ }$ & & $\begin{array}{l}\text { Pencarian jejak digital dari tor } \\
\text { browser dengan metode online } \\
\text { forensic }\end{array}$ \\
\hline (Noorulla, 2014) & & $\sqrt{ }$ & & Melakukan forensic file sistem \\
\hline
\end{tabular}

Wisnu Sanjaya et.al (Metode Offline Forensik Untuk Analisis Digital Artefak Pada TOR Browser Di Sistem Operasi Linux) 


\begin{tabular}{|l|l|l|l|l|}
\hline & & & $\begin{array}{l}\text { dan memori pada computer } \\
\text { dengan hasil Bukti digital masih } \\
\text { tersisa pada memori dan di } \\
\text { sebagian browser bukti digital } \\
\text { terdapat di file sistem }\end{array}$ \\
\hline (Sandvik, 2013) & $\sqrt{ }$ & $\sqrt{ }$ & $\begin{array}{l}\text { Menguji forensic browser pada } \\
\text { beberapa jenis browser dan system } \\
\text { operasi }\end{array}$ \\
\hline Solusi yang diusulkan & $\begin{array}{l}\text { Mengingat Masih sangat jarangnnya penelitian Browser Forensic pada } \\
\text { system operasi kali linux dimana sangat popular dan banyak digunakan } \\
\text { professional dibidang security yang sangat dimungkinkanya penggunaan } \\
\text { aplikasi anti forensic utk menghilangkan jejak, maka penulis berusaha } \\
\text { meneliti Jejak digital dari browser pd system operasi kali linux dengan } \\
\text { metode offline. }\end{array}$ \\
\hline
\end{tabular}

\subsection{Digital Forensik}

Digital forensik adalah cabang dari forensik yang berhubungan dengan pemulihan, investigasi dan analisis bukti yang ditemukan di perangkat digital yang dapat disajikan dalam pengadilan hukum. Saat melakukan penyelidikan harus mengikuti prosedur yang tepat dan protokol dan juga mendokumentasikan dari setiap tahapan saat mencari bukti digital [6].

Ungkapan forensik digital dan komputer forensik keduanya sering digunakan secara bergantian yang berarti ilmu memperoleh, mengambil, melestarikan, dan penyajian data yang telah diproses secara elektronik dan disimpan di media computer [7]. Sebagaimana yang disampaikan dalam penelitiannya oleh Lowman \& Ferguson yang berjudul Web History Visualisation for ForensicInvestigations [8].

Dari pengertian di atas, maka digital forensik juga dapat dibagi menjadi forensik komputer, forensik multimedia, forensik selular, forensik jaringan, forensik browser dan lainnya. Forensik web browser menjadi penting dalam forensik digital karena meningkatnya jumlah penipuan internet dan aktifitas ilegal lainnya seperti perjudian, prostitusi, perdagangan anak dan lainnya. Forensik web browser adalah kegiatan investigasi atau penyelidikan untuk menggali informasi yang dihasilkan dari web browser dan dapat dideteksi dari informasi yang diperoleh seperti history browser web, cache, cookie, temporary internet file dan bukti digital lainnya yang dihasilkan oleh sebuah web browser [9].

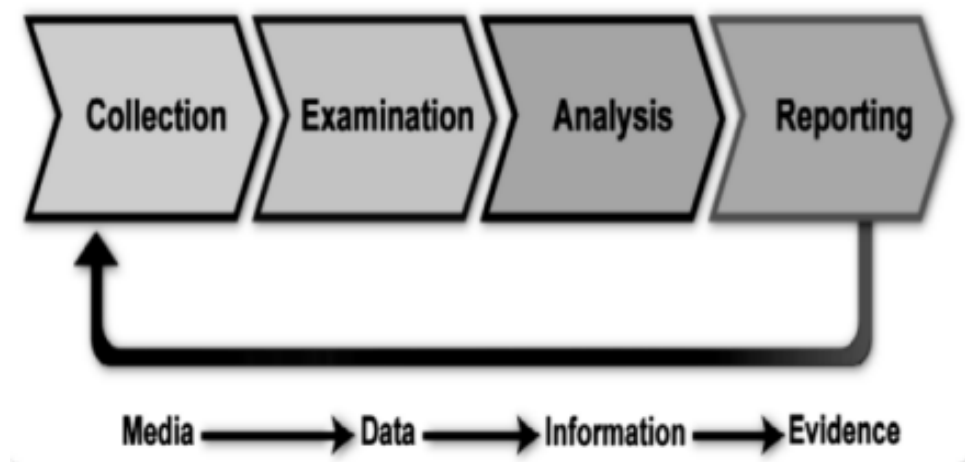

Gambar 2.2 Tahapan Proses Digital Forensik 


\subsection{TOR Browser}

Tor Browser adalah salah satu browser yang mampu menjaga anonimitas dan digunakan oleh mereka yang ingin terjaga privasi dan menghindari sensor saat browsing internet. Seiring waktu, TOR Browser terus dikembangan menjadi sangat baik dalam hal ini. Hal ini membuat keamanan, stabilitas, dan kecepatan jaringan meningkat.

Perkembangan browser Tor dimulai pada tahun 1995 dengan gagasan Onion Routing, yang dimaksudkan untuk melindungi komunikasi Internet di antara Intelijen Amerika Serikat Komunitas [5]. Arsitektur onion yang diusulkan untuk Metodologi routing, yang akan membatasi kerentanan jaringan dan analisis lalu lintas. Ide ini adalah sebuah proyek penelitian di Laboratorium Penelitian Angkatan Laut A.S., yang didanai oleh DARPA yang slogannya adalah, "menciptakan teknologi terobosan untuk keamanan nasional".

Pada tahun 1998, generasi pertama jaringan Onion Routing sedang dibangun. Sebuah makalah berjudul, "Anonymous Connections and Onion Routing "dirilis oleh David Goldschlag, Michael Reed, dan Paul Syverson dan memenangkan Alan Berman Research Publication Award tahun 1998. Penelitian tersebut menjelaskan tentang apa itu jaringan onion dan bagaimana ia beroperasi untuk kebaikan yang lebih besar berkaitan dengan privasi dan keamanan. Ketiga individu ini adalah pencipta asli browser Tor. Tujuan mereka adalah menggunakan Onion Routing untuk komunikasi anonim dan pribadi bidirectional melalui jaringan public.

Tabel 2.2 Cara Kerja TOR (https://www.torproject.org/about/overview.html.en)

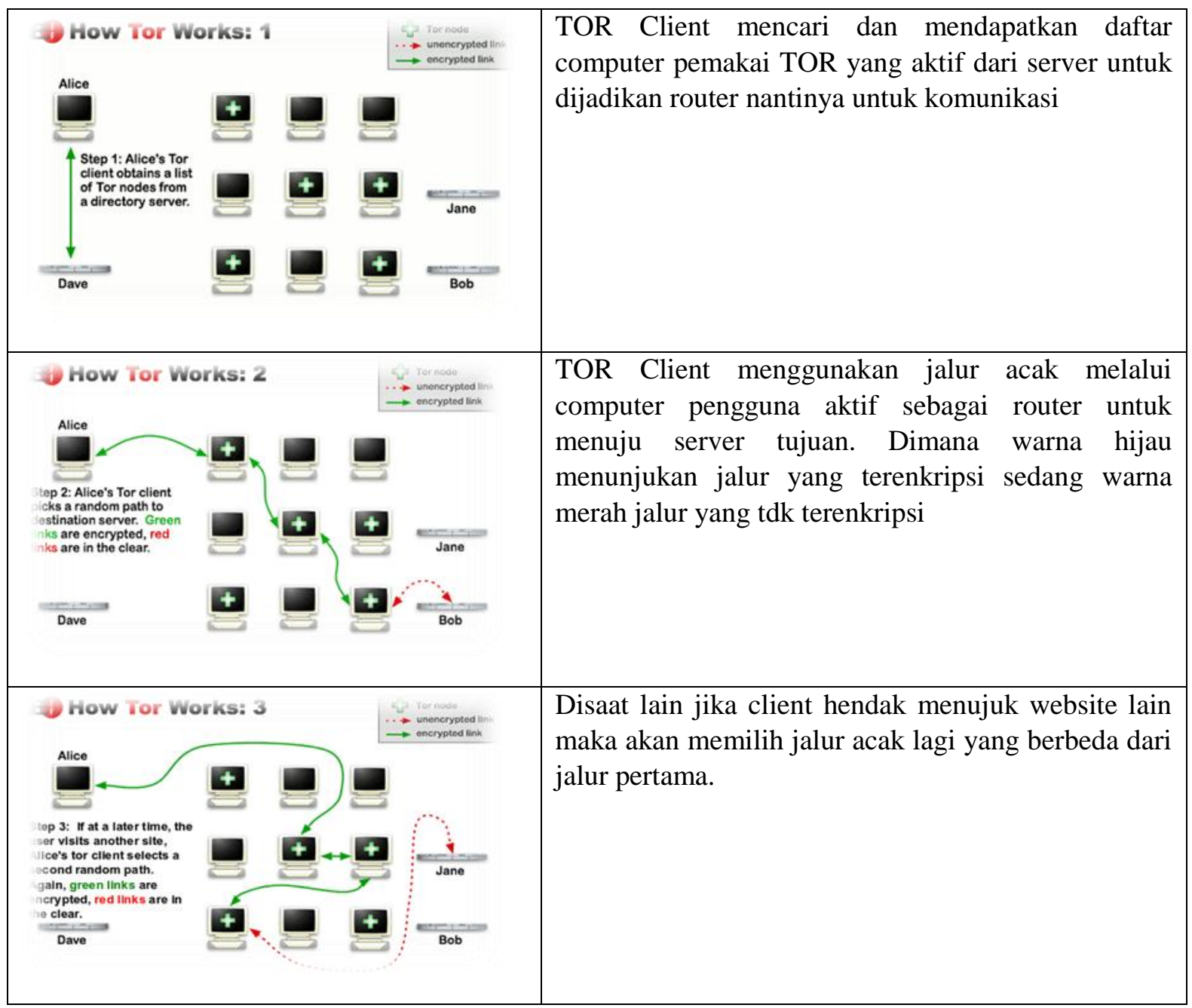




\subsection{Kali Linux}

Kali Linux adalah salah satu jenis distribusi linux yg dikenal cukup populer untuk kegunaan uji keamanan dan digital forensic. Kali linux memiliki banyak tools uji keamanan dan mampu berjalan di beberapa arsitektur computer[5].

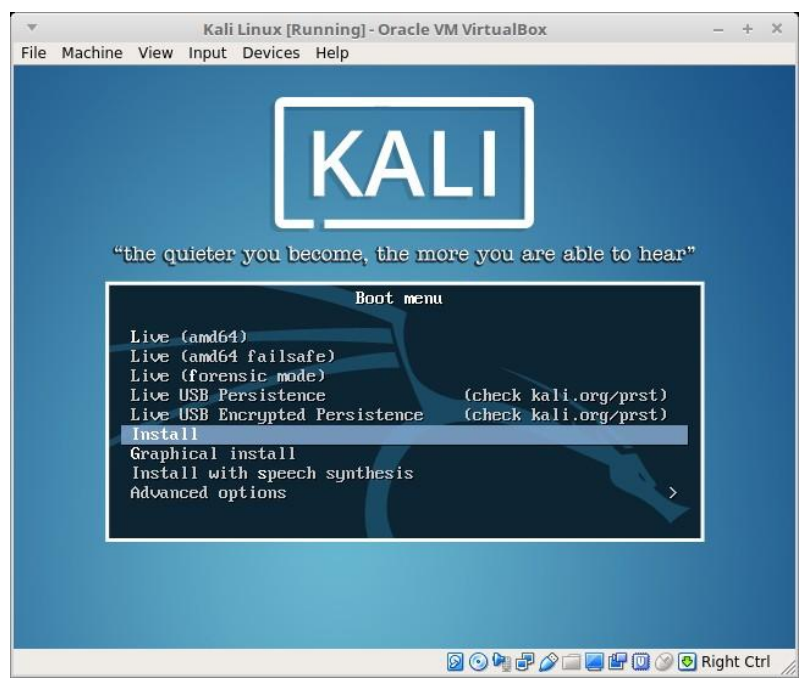

Gambar 2.4 Sistem Operasi Kali Linux

\subsection{Offline Forensic}

Analisa offline dalam forensik digital adalah proses investigasi yang dilakukan untuk mencari barang bukti dari sebuah barang elektronik yang sudah mati atau OFF. Dalam hal ini yang bisa dianalisa adalah berupa storage atau apapun yang di dalamnya akan menyimpan dari aktifitas pengguna.

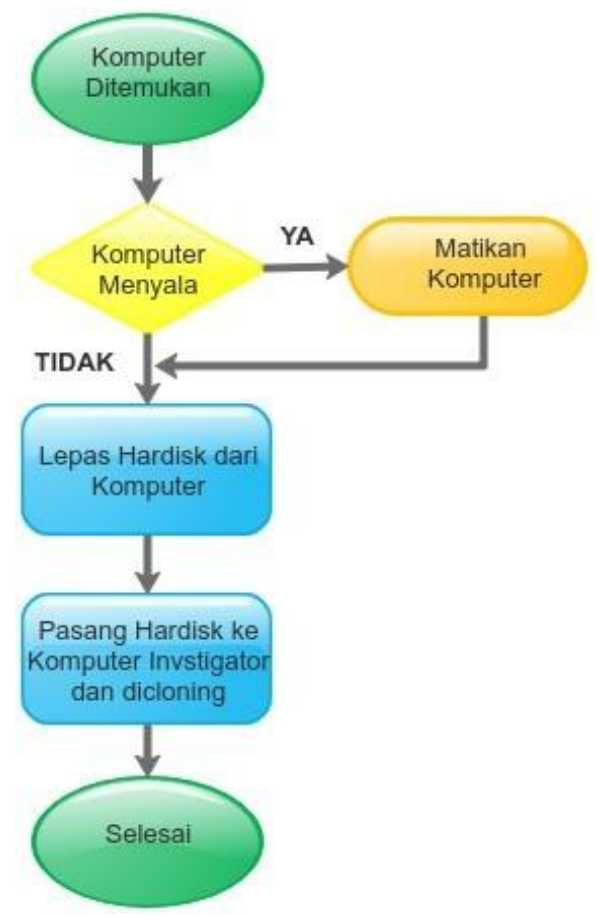

Gambar 2.5 Alur Offline Forensic 


\section{Metode Penelitian}

Dalam melaksanakan penelitian ini akan dilakukan tahapan-tahapan sesuai alur berikut.

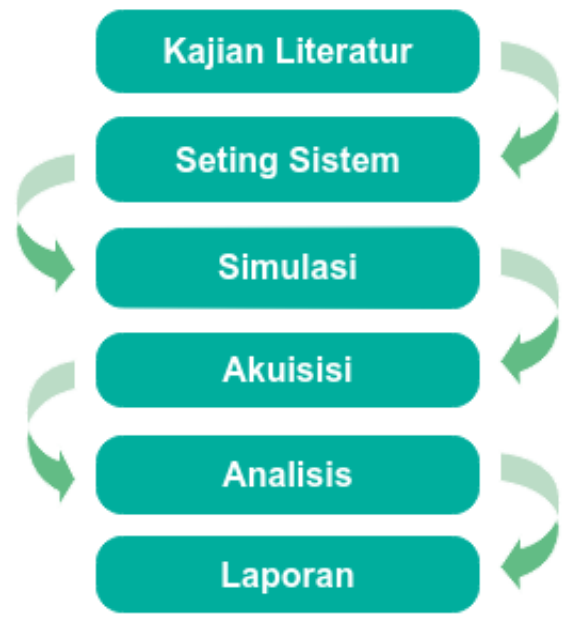

Gambar 3.0 Alur Penelitian

\subsection{Kajian Literatur}

Studi literatur digunakan untuk memahami tentang konsep, teori, dan hasil temuan penelitian lain yang serumpun dan akan dijadikan acuan sebagai landasan penelitian. Pada review penelitian berisi rangkuman dan hasil penelitian sebelumnya dengan topic yang terkait, sehingga bisa diperoleh perspektif baru dalam penyelesaian terhadap suatu masalah yang sejenis.

\subsection{Seting Sistem}

Sistem yang digunakan untuk melakukan penelitian semua berjalan dalam lingkungan Virtualisasi Menggunakan Perangkat Laptop dan Software Virtualbox

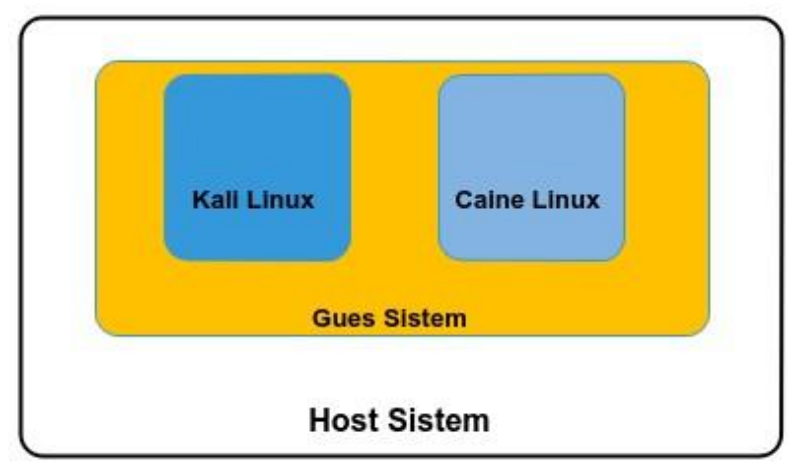

Gambar 3.2 Desain system

\subsection{Simulasi}

Untuk melakukan simulasi maka dibuat skenario dari penggunaan Kali Linux dan TOR Browser. Tahapan skenario diperlukan untuk menggali informasi, melakukan ujicoba sistem, dan pendalaman dalam memahami karakteristik digital artefak. Berikut ini merupakan topologi yang diterapkan pada penelitian ini.

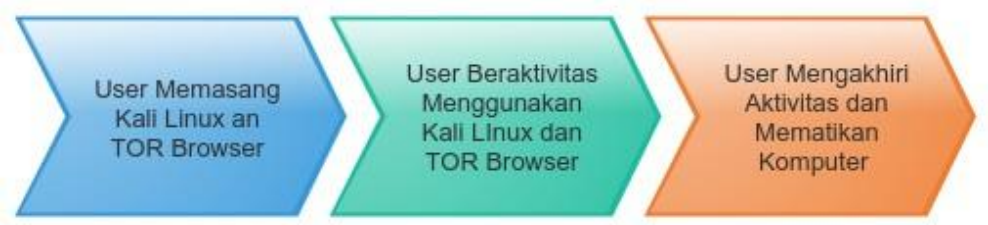




\section{Gambar 3.3 Alur Simulasi}

\subsection{Akuisisi}

Tahap akuisisi pada penelitian ini dilakukan secara offline forensic, dimana dilakukan dalam kondisi komputer tidak menyala, dan media penyimpan dilepas. Media penyimpan dihubungkan ke sistem utk forensic dan dilakukan write blocker untuk menghindari adanya perubahan data pada media penyimpan yang akan diakuisisi. Software Autopsy digunakan untuk melakukan akusisi barang bukti dalam upaya untuk menemukan bukti digital yang bisa menjadi petunjuk dari keberadaan dan aktivitas TOR Browser pada sistem operasi Kali Linux.

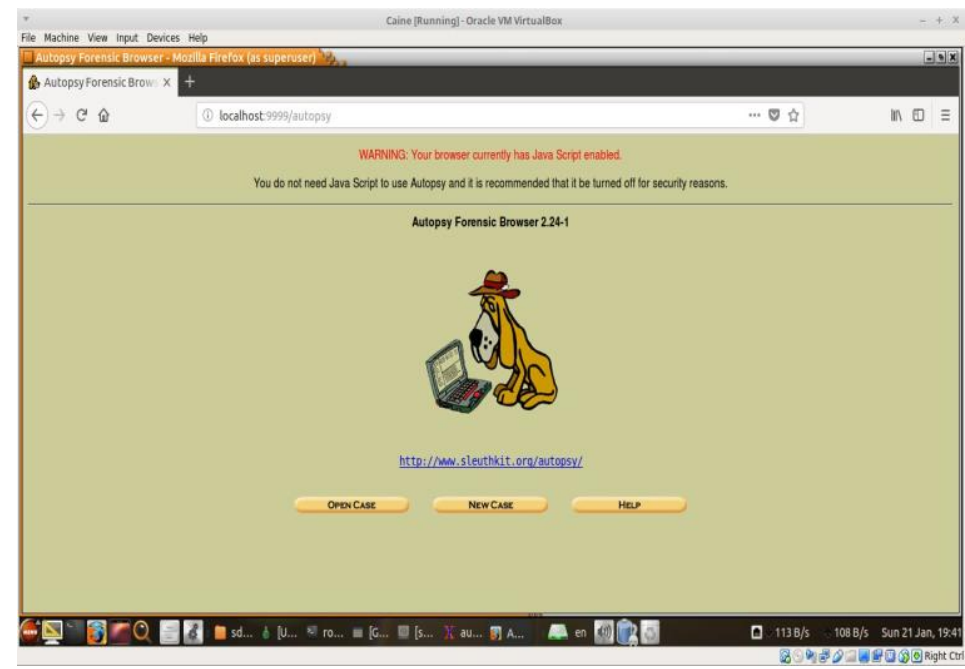

Gambar 3.4 Akuisisi dengan Autopsy

\subsection{Analisis}

Tahapan analisis ini digunakan untuk menganalisa barang bukti yang telah dilakukan akuisisi. Proses forensic yang dilakukan dalam penelitian ini akan mengambil fokus utama terhadap analisa data hasil aktivitas browsing menggunakan browser TOR berupa, cache, history, dan cokies. Komponen-komponen tersebut merupakan informasi yang dapat digabungkan untuk bisa menjawab kebutuhan informasi terkait dari mana sumber tindak kejahatan, dan waktu kejadian kejahatan.

\subsection{Laporan}

Tahap terakhir dari penelitian adalah membuat dokumentasi terhadap penelitian yang dilakukan secara keseluruhan agar bisa menjadi sebuah karya ilmiah dan memungkinkan sebagai referensi penelitian lain yang topiknya yang berkesesuaian.

\section{Hasil dan Pembahasan}

Berdasarkan dari metode penelitian dan melaksanakan tiap tahapan dari alur penelitian yang telah dibuat, maka diperoleh hasil dari penelitian untuk dilakukan pembahasan sesuai dengan kajian literatur

Setelah melakukan serangkaian persiapan, pada tahapan inilah dilakukan ujicoba terhadap datadata sehingga diharapkan akan memperoleh hasil yang bisa dijadikan bahan analisa untuk mengambil sebuah kesimpulan.

\subsection{Data}

Dalam proses offline forensic ini barang bukti utama yang ada yaitu storage media berupa hardisk, dikarenakan berasal dari sebuh system virtual maka hardisk yang ada berupa file image sesuai format virtualisasi. 


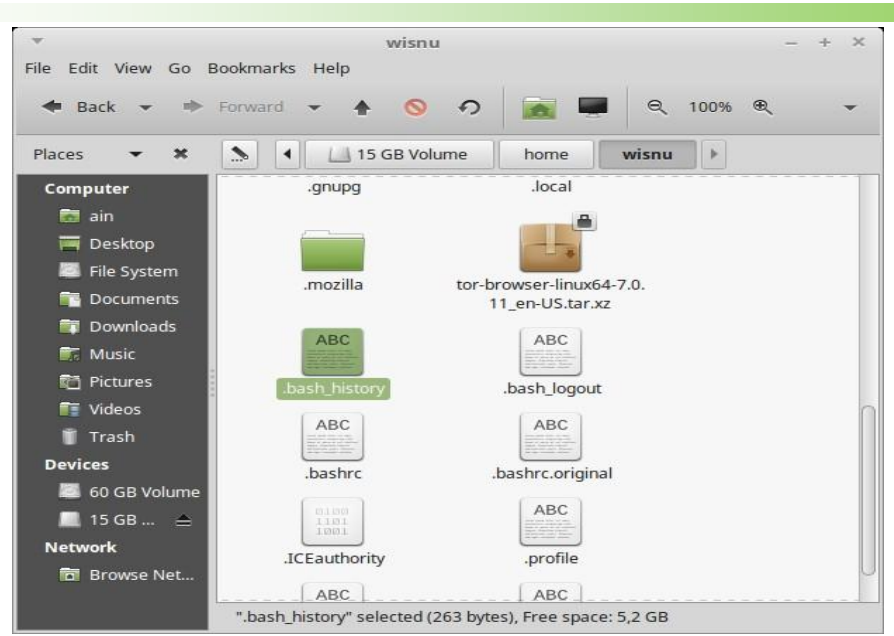

Gambar 4.1 Barang bukti

\subsection{Simulasi}

Dalam simulasi Kasus ini, untuk mendapatkan data dengan jumlah dan karakteristik yang variatif serta memadai maka akan dilaksanakan dalam beberapa skenario dari aktifitas pengguna. Simulasi implementasi forensic TOR Browser secara keseluruhan dijelaskan seperti bagan berikut ini.

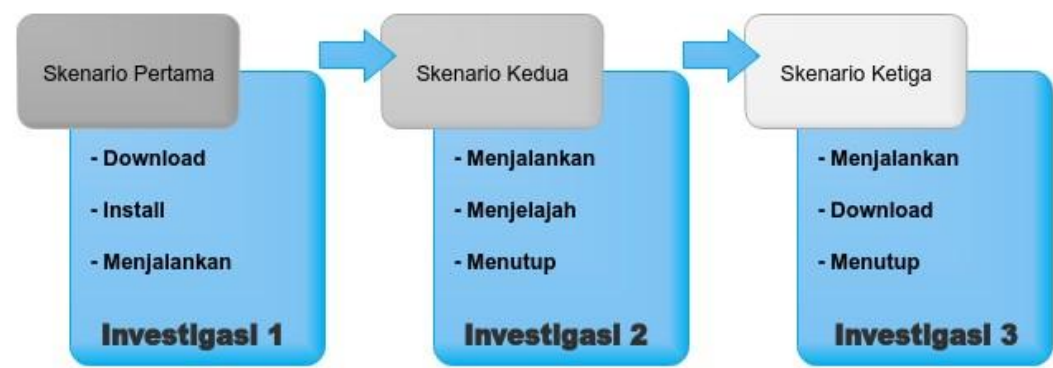

Gambar 4.2 Bagan Simulasi Kasus

\subsection{Hasil}

Hasil implementasi penelitian diperoleh dari akuisisi media penyimpanan baik berupa file-file $\log$, hasil download maupun pendukung lainnya.

Tabel 4.3 Hasil Akuisisi Bukti Digital

\begin{tabular}{|c|c|c|c|}
\hline Artefak & TOR Browser & Sistem Operasi & Keterangan \\
\hline Url history & 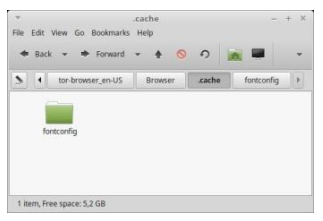 & - & Tidak ditemukan \\
\hline Cache & 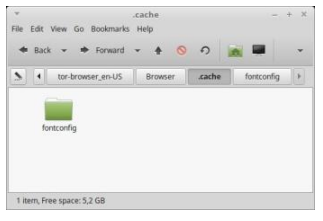 & - & Tidak ditemukan \\
\hline Cookies & 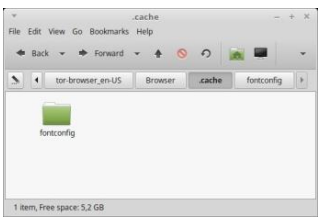 & - & Tidak ditemukan \\
\hline
\end{tabular}

Wisnu Sanjaya et.al (Metode Offline Forensik Untuk Analisis Digital Artefak Pada TOR Browser Di Sistem Operasi Linux) 


\begin{tabular}{|c|c|c|c|}
\hline $\begin{array}{c}\text { Bash } \\
\text { History }\end{array}$ & - & $\begin{array}{c}\text { Ditemukan dalam } \\
\text { log file } \\
\text { bash_history }\end{array}$ \\
\hline $\begin{array}{c}\text { Dowloaded } \\
\text { File }\end{array}$ & \begin{tabular}{|c|c|c|} 
hesh \\
Template-Laporan- \\
Tesis-MI-rev-21-12- \\
17-FIX.docx
\end{tabular} & - & $\begin{array}{c}\text { Ditemukan dalam } \\
\text { folder Download } \\
\text { dari TOR Browser }\end{array}$ \\
\hline
\end{tabular}

\section{Kesimpulan}

Berdasarkan hasil analisis forensic yang dilakukan bisa ditarik kesimpulan sebagai berikut Keberadaan penggunaan TOR Browser untuk aktifitas penjelajahan web bisa diketahui dari analisis log-log dari system operasi dimana TOR Browser tersebut dipasang. Jejak Digital dari TOR Browser ada yang bersifat tersimpan di media penyimpanan dan tidak tersimpan di media penyimpanan dan Tahapan Dalam melakukan Offline Forensic pada TOR Browser untuk analisis bukti digital meliputi: Imaging, validasi hashing, dan akuisisi.

\section{Ucapan Terima Kasih}

Terima kasih terucap untuk keluarga, pembimbing, rekan-rekan, almamater serta instansi terkait yang telah memberikan support kepada penulis sehingga penelitian ini bisa dilaksanakan dan selesai dengan baik.

Terima kasih juga terucap untuk Universitas Boyolali yang telah memfasilitasi journal JITU untuk melakukan publish, semoga JITU semakin berkualitas dan professional dalam pengelolaan dan penerbitannya.

\section{Daftar Pustaka}

[1] J. Oh, S. Lee, and S. Lee, "Advanced Evidence Collection and Analysis of Web Browser Activity", Digit Investig., vol. 8, pp. 63-70, 2011.

[2] Said, H., Mutawa, A.H., Awadhi, A.I., Guimaraes, M. (2011). Forensic analysis of privatebrowsing artifacts. International Conference on Innovations in Information Technology (IIT).

[3] K. Satvat, M. Forshaw, F. Hao, E. Toreini, "On The Privacy of PrivateBrowsing - A Forensic Approach (short paper)", Proceedings of the 8thInternational Workshop on Data Privacy Management (DPM'13), 2013.

[4] Syverson, P., Tsudik, G., Reed, M., Landwehr, C.: Towards an analysis of onion routing security. In: Federrath, H. (ed.) Designing Privacy Enhancing Technologies. LNCS, vol. 2009, pp. 96-114. Springer, Heidelberg (2001)

[5] Shree Krishna Lamichhane, Penetration Testing In Wireless Networks. Thesis 2016

[6] Noorulla, E. S. Web Browser Private Mode Forensics Analysis. (2014)

[7] Kruse \& Heiser, 2002.Kruse, W.J. and Heiser, J.G., 2002. Computer forensics incident response essentials. New York: Addison Wesley.

[8] Lowman, S., \& Ferguson, I. (2012). Web history visualisation for forensic investigators. Forensic 
Focus. Retrieved from http://articles.forensicfocus.com/2011/07/26/web-historyvisualisationforforensic-investigations/ on 10 December 2012.

[9] G. Dharan, "Forensic Evidence Collection by Reconstruction of Artifacts in Portable Web Browser," 2014.

[10] Adautin, E. D., \& R, N. M. A. (2015). Forensic Reconstruction and Analysis of Residual Artifacts from Portable Web Browser, 128(18), 19-24.

[11] Al-Khaleel, A., Bani-Salameh, D., \& Al-Saleh, M. I. (2014). On the Memory Artifacts of the Tor Browser Bundle. Proceedings of the International Conference on Computing Technology and Information Management, 41-46.

[12] Babincev, I., \& Vuletic, D. (2016). Web application security analysis using the Kali Linux operating system. Vojnotehnicki Glasnik, 64(2), 513-531. https://doi.org/10.5937/vojtehg64-9231

[13] Christensson, P. (2010). Log File Definition.

[14] Hassan, N. F., \& Jaber, H. M. (2017). Offline vs . Online Digital Forensics of Cloud - based Services, 20(4), 117-124. https://doi.org/10.22401/JUNS.20.4.18

[15] Keller, K. (2016). The Tor Browser A Forensic Investigation Study.

[16] Kolhe, M., \& Ahirao, P. (2017). Live Vs Dead Computer Forensic Image Acquisition. International Journal of Computer Science and Information Technologies, 8(3), 455-457.

[17] Mulazzani, M. (2014). New challenges in digital forensics: online storage and anonymous communication, 2014.

[18] Rochmadi, T. (2017). Analisis Anti Forensik pada Portable Web Browser Mode Private Menggunakan Metode Live Forensik.

[19] Sandvik, R. A. (2013). Forensic Analysis of the Tor Browser Bundle on OS X, Linux, and Windows, 113. 